\title{
Transgressing Gender Boundaries: The Function of the Fantastic in Jeanette Winterson's The PowerBook
}

\section{Mine Özyurt Kılıç}

To cite this article: Mine Özyurt Kılıç (2008) Transgressing Gender Boundaries: The Function of the Fantastic in Jeanette Winterson's The PowerBook, English Studies, 89:3, 287-304, DOI: $10.1080 / 00138380802011925$

To link to this article: https://doi.org/10.1080/00138380802011925

曲 Published online: 04 Jun 2008.

Submit your article to this journal $\pi$

Џ Article views: 283

4 Citing articles: 1 View citing articles 지 


\section{Transgressing Gender Boundaries: The Function of the Fantastic in Jeanette Winterson's The PowerBook} Mine Özyurt Kılıç

When asked by an interviewer to define her key themes in The PowerBook, Jeanette Winterson replied "Oh, boundaries, desire, time, identity." As most critics agree, Winterson reworks the themes that she has treated in her previous novels. Although some may think that Winterson merely repeats herself, she notes that she sees these novels as "a cycle or series": 2

And they interact and themes do occur and return, disappear, come back amplified or modified, changed in some way, because it's been my journey, it's the journey of my imagination; it's the journey of my soul in those books. So continually they must address one another. ${ }^{3}$

Ali, the e-storyteller in the novel, also identifies the themes in the novel she is currently writing as, "Boundaries. Desire". 4

The PowerBook is based on the idea that cyberspace provides drastically different and varied possibilities for people to communicate with each other. The book draws on the opportunities for crossing boundaries that cyberspace offers to individuals; so it is a play on the idea of cyberspace, changing identities and possible emotional interaction. Employing this theme of boundary-crossing via the Internet, the novel becomes a medium for transgressing the boundaries of gender roles as well. With the help of some fantastic images, The PowerBook serves as a book of power from which readers can draw strength to deconstruct the established gender roles assigned by patriarchal ideology. The images of metamorphosis and cyberspace function to efface the limits of patriarchy. Concepts like the real nature of the virtual world and the thinness of the line between the real and the imaginary also increase the transgressive

Mine Özyurt Kılıç is affiliated with the Department of English Language and Literature, Bilkent University, Ankara, Turkey.

${ }^{1}$ Reynolds and Noakes, 25.

${ }^{2}$ Ibid., 5.

${ }^{3}$ Ibid.

${ }^{4}$ Winterton, 35. All subsequent page references to Winterson's The PowerBook are given in the text. 
effect of the fantastic. Moreover, the criticism of the patriarchal family structure and the presentation of lesbianism as the surest ways to survive love and passion are reinforced by these fantastic images. The PowerBook shows lesbianism as the only real emancipation from patriarchal norms; it also demythologises motherhood, which essentialist feminists use as a weapon against patriarchy. This paper focuses on the subversive function of the fantastic images in Winterson's The PowerBook, following the definitions of Tzvetan Todorov and Rosemary Jackson.

The story starts in a virtual world with an e-mail "Freedom, just for one night" (3). Winterson alludes to lovers in the past meeting each other secretly at night when all others are sleeping, and makes Ali speak in a similar fashion: "Did anyone see you?", as if the virtual entry of the woman on her screen could be seen by the people next door (4). With Ali's comment on the setting to the story, the reader is drawn into a process of questioning what it means to make a communication real:

This is where the story starts. Here in these long lines of laptop DNA. Here we take your chromosomes, twenty-three pairs, and alter your height, eyes, teeth, sex. This is an invented world. You can be free just for one night.

Undress.

Take off your clothes. Take off your body. Hang them up behind the door. Tonight we can go deeper than disguise. (4)

By mentioning chromosomes and the possibility of changing one's height, eyes, teeth and sex, Winterson also employs the theme of identity and identity management. Apparently, cyberspace allows people to change their identities and enables them to adopt roles as different individuals. This freedom to alter one's identity, or to express an imaginary one, causes problems for the concept of identity: It is a "tricky phenomenological" 5 case in which the real stands in opposition to fantasy. Thus, one is left with the question, "What's one's TRUE identity?"6 Winterson's Ali handles this question and speculates on it as she says she talks to people in cyberspace "whose identity [she] cannot prove" (94).

Winterson sets cyberspace in sharp opposition to "meatspace", and she uses the term "meatspace" to denote the flesh-and-blood existence of two people in a real room, rather than in chat rooms on the Internet (159). Her choice of Spitalfields as one of the places where the story takes place in the novel also ironically emphasises the idea of meatspace, since it is London's meat market. Also, a meat market, is slang for a place where men can size women up as if they were so much meat. It is also a play on "meet market", where men and women meet each other which recalls Luce Irigaray's article "Women on the Market". 7 Winterson herself notes that she uses Spitalfields extensively in the novel "because that's a place where there is layer upon layer of life from Roman Britain, through Elizabethan times, the Georgian period,

\footnotetext{
${ }^{5}$ Suler, 4 .

${ }^{6}$ Ibid.

${ }^{7}$ Irigaray asserts that patriarchy reduces women into commodities and that "women has value only in that she can be exchanged" (176).
} 
into the life of the fruit and veg market in the twentieth century." ${ }^{8}$ By this statement, Winterson also shows how conscious she is of history. The idea of cyberspace, which stands in sharp opposition to meatspace, permeates the book, not only in the content but also in the cover and the title. The hardback 2000 edition is designed in such a way that, with its black square shape, it very much resembles a set of compact discs. Thus, the reader is meant to touch his/her personal The PowerBook as if it were a PC with the CDs in it to be played at home. The chapter titles are also from computer jargon, which heightens the effect of virtual reality within the novel. The term MENU replaces the traditional "Table of Contents". In the same way, chapter titles such as, “OPEN HARD DRIVE", “NEW DOCUMENT”, “SEARCh”, “VIEW”, “VIEW AS ICON”, “EMPTY TRASH”, “special”, “help”, “Show balloons”, “Chooser”, “Quit” “Really quit?”, “Restart” and "SAVE" are also taken from Microsoft Word. More importantly, these titles function as the thematic signifiers of each chapter. For instance, in the chapter "EMPTY TRASH", Alix gives an account of the hard life she has had in her childhood. The sharp gender boundaries in the family annihilate the existence of Alix as a girl. She can escape death only by living in disguise as a boy; not being tolerated as a girl, she is brought up to act as a boy. Looking at the title in the light of the content, one cannot help but think that Alix literally "empties the trash" she has in her mind. In this way, Winterson implicitly maintains that those memories that one may have in such a patriarchal family are merely trash. Likewise, in the chapter called "SEARCH", in which the tragic love story of Lancelot and Guinevere is told, everything is centred on Lancelot's search for the true feelings of his heart. Consequently, the titles from computer jargon emphasise that the novel is presented as a virtual world with stories resembling those in the real world.

This "virtual world", which is one of the subtitles, is also a source of the fantastic in this novel (61). With the image of a computer screen through which one can enter into the new world of cyberspace, the novel plays on the idea of problematisation of vision, which is one of the main characteristics of the fantastic according to Todorov. ${ }^{9}$ Winterson asks whether what one sees on the screen through the Internet

\footnotetext{
${ }^{8}$ Reynolds and Noakes, 20.

${ }^{9}$ In his seminal study The Fantastic: A Structural Approach to a Literary Genre (1975), Todorov highlights the function of vision and its problematisation as one of the denominators of the fantastic. He maintains that it is sight that alters a real and ordinary world into a fantastic one:
}

It is eyeglasses and mirrors that permit penetration into the marvellous universe.... Real wealth,
true happiness are accessible only to those who manage to see themselves in the mirror.... To see
through eyeglasses brings the discovery of another world and distorts normal vision.... Vision pure
and simple reveals an ordinary world, without mysteries. Indirect vision is the only road to the
marvellous. (121-2)

Robert Louis Stevenson's Dr Jekyll and Mr Hyde (1886), one of the early works of the genre, is based upon this very problem. There, in the experimental realm of Dr Jekyll, Hyde appears and then disappears "like a breath upon a mirror." There it is that certain drugs have the power "to shake and pull apart our covering of flesh, just as the wind might blow a curtain aside" (Stevenson, 10). Stevenson's novel represents an important example of the fantastic. In almost all fantastic works, sight, seeing and vision is problematised; or rather vision becomes a significant device of the fantastic. Todorov, calls this a "fundamental sense, sight" (120). He asserts that sight is one of the important components of the fantastic by referring to Hoffmann's tale, "Princess Brambilla", the 
is true or not. However, Winterson's The PowerBook explores the problem of vision in a different fashion. The device of indirection, here, is not a telescope, a microscope or eyeglasses as it usually is in traditional fantastic tales like "The Sandman" or "The Vampire". In the novel, it is the screen of a computer which helps the user to penetrate into an unfamiliar world, and which functions as the apparatus to distort and subvert vision. In this virtual world, perception is different than in the everyday world. By following the instructions of a software programme, the reader can enter and search for the storyline. Similarly, the narrator of the story, Ali, writes, then rewrites and saves her story on the screen. As she tells her story, she takes the reader from sixteenth-century Ottoman Turkey to modern London, and introduces many different stories with the same theme. The screen therefore functions as a navigator.

Looking at some of the images in The PowerBook, one can see that these fit into the category of Todorov's "theme of self" ${ }^{10}$ since they problematise vision/perception by making use of cyberspace as one of the planes of reality in the novel. The plot of the novel is centred on a love affair that starts in cyberspace; Ali corresponds with her lover via the World Wide Web. Her lover is married to a man, and this couple are physically together, yet the physical proximity does not leave her lover spiritually satisfied; as Jeannine DeLombard states, in Winterson's tale, “The much-vaunted liberatory possibilities of cyberspace add merely another dimension to the itinerant possibilities of all prose, the seduction of all narrative." ${ }^{11}$ While the narrator of the novel, Ali, is sitting at her screen, she receives an e-mail and "unwrap [s]" it and finds a message; the message reads "Freedom, just for one night" (3). Then, transgressing the boundary between the screen and her mind, that is matter and mind, she starts to refer to the object as if she were actually, not virtually, in a room:

Freedom for a night, you say. Just for one night the freedom to be someone else. Did anyone see you arrive? No. Then I can pull the blinds and light the lamp. The clock ticks, but only in time. From outside, looking in, there will be only a movement of shadows - the looming of a bear's head, a knife. You say you want to be transformed. (4)

The virtual world that she can enter via the screen is where the story starts for Ali and her lover. In cyberspace, together with her lover, Ali feels that she belongs to a different time-scale which gives them the freedom to be transformed into other

theme of which he states as "the play of dream and reality, mind and matter" (Todorov, 121). There, like the computer screen in The PowerBook, vision offers the dividing line between the real and the fantastic. Similarly in E. T. A. Hoffmann's "The Sandman", it is love at first "sight" that accelerates the conflict of the protagonist. The tale contains the ocche, eye-glasses and telescope that bring together the sight of the automaton and the fiery Sandman who collects the eyes of small children for his own children who live on the moon; while in Theophile Gautier's "The Beautiful Vampire", the problem starts with "the effect of sea-green eyes. ...What eyes!" which makes Romuald experience the "sensation of a blind man who suddenly recovers his sight" and ends with relevant advice to the reader: "Never look on a woman, but go with your eyes fixed on the ground, for chaste and steadfast as you may be, one minute may make you lose Eternity" (Gautier, 259).

${ }^{10}$ Todorov, 139.

${ }^{11}$ DeLombard, 24-5. 
people. The things one writes with the keyboard on the screen allow an easier alteration of identity than fantasy can provide; Ali likens the keys to the limitless possibilities that DNA offers to a human being.

In the chapter entitled "Virtual World", Ali questions the nature of this virtual world. Though she is aware of the fact that she should expect not a real but a virtual world, she still cannot help being sensitive to the messages. The loneliness and desperation she feels are real enough to make her feel like a "penitent in a confessional" (63). Then, as she receives no message from her lover, she starts to ask:

What did I expect?

This is a virtual world. This is a world inventing itself. Daily, new landmasses form and then submerge. New continents of thought break off from mainland. Some benefit from a trade wind, some sink without trace. Others like Atlantis-fabulous, talked about, but never found.

I'm looking for something, it's true.

I'm looking for the meaning inside the data.

That's why I trawl my screen like a beachcomber-looking for you, looking for me, trying to see through the disguise. I guess I've been looking for us both all my life. $(63-4)$

It is evident that the screen as a medium starts to become the way to the marvellous where the boundary between "I" and "you" collapses. As Ali searches for her lover, she says she will also be looking for herself. In the part called "meatspace", Ali elaborates on the form of communication in the virtual world. The dialogue between the two lovers on the net suggests the real nature of the relationship in the virtual universe:

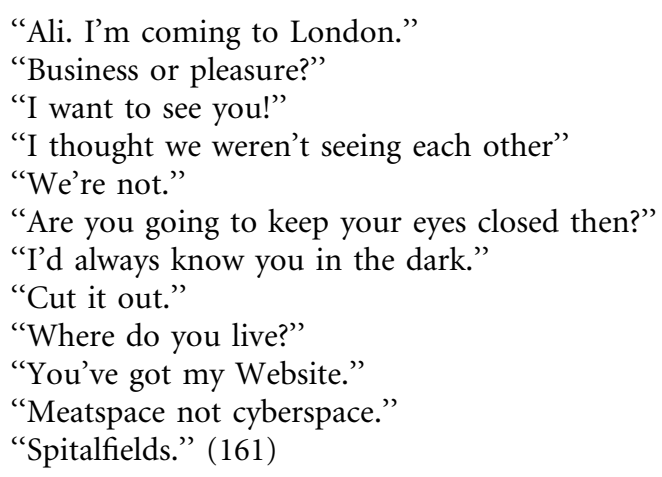

Later, when they meet, following the mirror metaphor that describes the love between two women, Ali says: "You kiss me and the glass grows cloudy. I stop thinking. Meatspace still has some advantages for a carbon-based girl" (174). By mixing the mirror image in meatspace with the screen of cyberspace, Ali voices her faith in the truth of love in cyberspace, despite the fact that meatspace offers some fleshly 
advantages. Interestingly, her lover can lie to her very real husband with whom she lives together in "meatspace", but she cannot do the same thing as easily to Ali on the net. This shows the "real" nature of the virtual world. Ali criticises her lover because she does not think of leaving her husband in spite of her love for Ali; in her criticism, Ali questions the nature of heterosexual love and marriage. She does it by reverting to the crucial components of life, such as time and space:

Inside her marriage there were too many clocks and not enough time. Too much furniture and too little space. Outside her marriage, there would be nothing to hold her, nothing to shape her. The space she found would be outer space. Space without gravity or weight, where bit by bit the self disintegrates. (39)

In the scene where Ali as the narrator describes the love-making between herself and her lover, the effacement of limits is delineated. Through the description of the love-making between two women, Ali describes how one becomes the other. The description demonstrates the ultimate aim of using the fantastic in this novel- the effacement of limits:

Let me in. You do. In this space which is inside you and inside me I ask for no rights or territories. There are no frontiers or control. The usual channels do not exist. This is the orderly anarchic space that no one can dictate, though everyone tries. This is a country without a ruler. I am free to come and go as I please. This is Utopia. It could never happen beyond bed. This is the model of government for the world. (175)

She defends lesbianism in the face of the heterosexual counter-argument that it is not a life-enhancing philosophy because it is not reproductive. With such a counterargument in mind, Ali, the narrator, prepares a refutation as she metaphysically reflects upon the life of bacteria. Comparing the reproductive sex life of heterosexuals to the life of bacteria, she derides heterosexual ideology for being aimed at discipline and family in the name of reproduction. She shows the futility and lifelessness of such lives:

Sex. How did it start? In the strange dark history of our evolution, there was a shift, inevitability, away from self-reproducing organisms-like bacteria-towards organisms which must fuse with one another to survive. You see, bacteria know the secret of eternal life. They do not die unless something kills them. They don't change, they don't age, all they do is multiply. (175)

It is evident that Winterson proposes a different order that shatters the physical and spiritual assumptions of heterosexual love, and this new love, lesbian love, is seen as the only alternative to the heterosexual love that seeks a ruler, that wants to dictate and control with its rights, territories and frontiers. She also stresses the tyranny of heterosexual life by calling the time spent in the mother's womb "captivity" (157). Since most lesbians choose not to become mothers, Winterson's demythologising of motherhood functions as a defence of lesbianism. Ali says that her parents "bred" her 
"unexpectedly" and "unwanted" like "sheep and pigs", and she says, "they did [her], and quickly too" (156): "[My mother's] voice was soft-like the river over the chalk pan of the riverbed. You will say I never heard it, but I heard it every day in the nine months that I was her captive or she was mine" (157). The way she talks of her origins serves as a demythologising of the family because the family life that made her physical existence possible completely lacked spiritual satisfaction; this helps Ali to make the auditors of her tale accept her argument that heterosexual love and sex life are not the only ways to happiness, in fact they often make people unhappy. She follows an anarchic strategy. That is, she attempts to break the boundaries of this order. She calls the anarchic space, this sex between women, "mirror geography" (174) where one can see oneself in flesh and blood: "You are a looking-glass world. You're the hidden place that opens to me on the other side of the glass.... You are what the mirror reflects and invents. I see myself, I see you, two, one, none" (174). Here, Winterson seems to allude to Jacques Lacan's term the "mirror stage", ${ }^{12}$ in which a child sees herself as Other. According to Lacan, there is a gap between the two "I"s, the seen and the onlooker, and in order to bridge this gap which in fact signifies the gap between the child and the world outside the child, she enters the symbolic order through language. ${ }^{13}$ This symbolic realm is also interpreted by Lacan as the law of the father, through which the child realises the fact that mother lacks a penis, thus, father has more power in the world outside. ${ }^{14}$ By using the term "mirror geography" for the love between two women, Winterson implies the similarity of this space between women to the imaginary stage which is the stage experienced before entering into the symbolic stage, the law of the father.

In its employment of the mirror as a tool for problematising identity, the novel gains a fantastic dimension in Leo Bersani's terms as well. In his A Future for Astyanax: Character and Desire in Literature (1976), Bersani stresses the central role the mirror plays in literature "as a metaphor for the production of other selves". ${ }^{15}$ The distance created by a mirror constructs a different realm that alters the individual's notions of self. He explains this as "a spatial representation of an intuition that our being can never be enclosed within any present formulation here and now-of our being". ${ }^{16}$ In this way, the mirror provides versions of ourselves transformed into another, becoming something or someone else. ${ }^{17}$ Rosemary Jackson points out that many fantasies employ mirrors that either distort vision or transform the familiar into the unfamiliar. ${ }^{18}$ Todorov also emphasises the significance of mirrors that "permit penetration into the marvellous universe". ${ }^{19} \mathrm{He}$ also contends

\footnotetext{
${ }^{12}$ Lacan, 6.

${ }^{13}$ Ibid.

${ }^{14}$ Ibid.

${ }^{15}$ Bersani, ix.

${ }^{16}$ Ibid., $\mathrm{x}$.

${ }^{17}$ Jackson, 87.

${ }^{18}$ Ibid., 45.

${ }^{19}$ Todorov, 121.
} 
that the use of a mirror in fantastic texts "constantly emphasizes the problematic nature of perception"; thus he categorises such images under the "theme of self" by referring to the Freudian "perception-consciousness system". ${ }^{20}$ In a sense, the mirror becomes the medium for the reader to move into the marvellous plane in which the limit between the subject and object collapses. In a parallel fashion, the tyranny of gender roles and patriarchal ideology also collapses.

Another way in which The PowerBook criticises the patriarchal order is by using other fantastic themes of self in Todorov's categorisation, such as the transformation of the concepts of time and space. As the narrator states at the close of the novel, deconstructed time and space can be seen as the framework that supports the thematic network of The PowerBook: "No date line, no meridian, no gas-burnt stars, no transit of the planets, not the orbit of the earth nor the sun's red galaxy, tell time here. Love is the keeper of the clocks" (244). It's important here that this statement is not a poetic or allegorical expression that would, according to Todorov, put an end to the fantastic; the metaphor becomes literal. In other words, the statement that love's time is different is not a metaphor; in practice, it can be understood by the fact that the existing, invented forms of measurement cannot tell us anything about the nature of time. The narrator equates time with life, and implies that time is something tangible, not an abstraction as theorised by scientists. Thus, minutes and hours counted by clocks have a power which is real enough to change the course of our lives. The idea that time is substantial is also verified by the narrator's ritualistic act: "I took my watch and dropped it into the water. Time take it. Your face, your hands, the movement of your body.... Your body is my Book of Hours. Open it. Read it. This is the true history of the world" (243).

Ali's refusal to see time as something abstract can be seen as a rebellion against the limitations of time. Walking down to the Thames, she meditates upon the passage of time and its mark on the river. The dirty Thames becomes the centuries solidified in front of her eyes, as she thinks that it is the past pumped through time and taken out to sea: "Mammoths used to drink from the shallow sandbank. This is a Roman river, an Elizabethan river. This is the route to the Millennium Dome" (243). The use of the present tense for the Roman era and the Elizabethan time again signifies that time for the narrator does not conform to conventional notions of time; accordingly, she feels time differently, not by glancing at the timepiece on her wrist but by dipping her hands in the water; as she does so, she feels that it is: "Liquid time" (243). With the Todorovian interpenetration of the physical and the spiritual worlds, the "fundamental categories" like time and space are "modified as a result": "The time and space of the supernatural world, as they are described in this group of fantastic texts, are not the time and space of everyday life." 21 The PowerBook brings forth a new categorisation of time, not only by making the everyday concept of time null and void but also by repairing the distortion that this "time" has caused. Winterson finds

\footnotetext{
${ }^{20}$ Ibid., 120.

${ }^{21}$ Ibid., 115.
} 
an essence that defies all kinds of divisions when the boundaries of time are transgressed:

What exists and what might exist are windowed together at the core of reality. All the separations and divisions and blind alleys and impossibilities that seem so central to life are happening at its outer edges.... Beyond time, beyond death, love is. Time and death cannot wear it away. (109-10)

This essence that defies all definitions and borders such as time and space, is love. Winterson presents Ali engaged in her narrative attempts to bridge the gap between different times and different spaces. She tries to put the pieces of tragic love stories together by acting as the centre for them and as the storyteller of the novel. In Winterson's words, she seems to "wrap a moving story-the story of a love affairaround certain iconic moments, like Paola and Francesca, Lancelot and Guinevere, the story of Mallory, and that was the choice." 22 The stories in the novels are taken from different historical periods and from different geographical locations. With this juxtaposition of different times and characters, Ali's act of storytelling, thus, functions to cross the boundaries of time and space. Ali herself explains why she keeps on telling stories, the story of "you", the story of "me" and the story of "others": "because a story is a tightrope between two worlds" (119). Through these stories, she slips between the gaps in history "as easily as a coin rolls between the floorboards" (215). The stories she tells have "no date", they are "simultaneous with time" (216). Although the stories have no date, to Ali they are guidelines, or "maps", that show people the route to be followed (54). In a sense, Winterson asserts that by reading other people's stories about love, readers become able to make the right decisions for themselves in their own love stories:

The stories are maps.... A Marco Polo route through territory real and imagined. ... In these wild places I become part of the map, part of the story, adding my version to the version there. This Talmudic layering of story on story, map on map, multiplies possibilities but also warns me of the weight of accumulation. (54)

During the course of her narrative, by cross-dressing, by acting in a very wide time span from the sixteenth century to the twentieth century, and in a wide geographical space stretching from Ottoman Turkey to modern London, the same topic, love, is on the focus. In this way she suggests that wherever one is, whatever time s/he lives in, patriarchy makes its tyranny felt, and one needs to fight for one's right to free love and sex. Thus, she tells the tragic stories of "great and ruinous lovers", of Lancelot and Guinevere, and of Francesca da Rimini and her lover Paolo, of George Mallory and Irvine among many others (75). In order to show how meaningless time is when love's universality is considered, Winterson solidifies the image of time by evoking Mallory's watch broken into pieces on top of Mount Everest. He reaches the

$\overline{{ }^{22} \text { Reynolds and Noakes, } 26 .}$ 
peak of the mountain, but as it is very cold, his life is in jeopardy; just as he tries to save himself, he breaks his watch and the glass breaks. With this image of a watch breaking into pieces, Winterson plays on the theme of time and ridicules those who cling to their timepieces as limiting them in time and space: "[Mallory] started to laugh and then he couldn't stop laughing, because it was so silly really, his watch going tick, tick, tick, when time had stopped long since and there was no time. Not here. They were outside time, he knew that" (152). The same devaluing attitude towards time is also present in Ali's story of the tulip. The narrator jumps from the sixteenth-century Ottoman setting to twentieth-century England, and says that this slip in time is done on purpose: "I wanted to make a slot in time. To use time fully I use it vertically. One life is not enough. I use the past as a stalking horse to come nearer to my quarry" (209). This statement also explains why Ali keeps on telling us about other lives.

Various love stories inserted into the main plot line have the functions of making the reader see this story from a distance, and of creating a sort of Verfremdungseffekt that detaches the reader from the emotional density of love. In this way, the lesbian relationship can easily be cited among the traditional love stories. Recounted together with these famous love stories, a lesbian love story also becomes speakable. Winterson achieves this by reverting to the story-telling technique which makes Ali both the storyteller and the critic. For instance, Ali's critical comment, the idea that the line between the real and the imaginary is thin becomes an overarching statement for the novel itself. As she states in another chapter, the line between the two realms is very thin: "The more I write, the more I discover that the partition between real and invented is as thin as a wall in a cheap hotel room" (93).

In the story of Francesca da Rimini and Paolo, the line between the two separate worlds, the real and the imaginary, seems to collapse as they make love and fall in love. They move so swiftly that they almost lose contact with the earthly limitation of gravity. This freedom from physical restraint immediately follows the emotional freedom they experience, namely the act of discarding Gianciotto, Francesca's husband, who is Paolo's brother. The love between Francesca and Paolo transgresses the boundaries of the marriage bond between Francesca and her husband. Upon seeing Francesca and Paolo making love, Gianciotto kills them, and Francesca describes the moment of death as a transgression of the line between the real and the fantastic: "We are as light now as our happiness was, lighter than birds. The wind carries us where it will, but our love is secure. No one can separate us now. Not even God" (129). The story of Francesca and Paolo is enveloped in the parallel story of Lancelot and Guinevere which also involves a triangle composed of the husband, the wife and the lover. As the lovers in the former story read the story of the latter-as the couples merge in the world of imagination-the common theme of the two stories is rendered more visible. Through this and as the title of this part of the book suggests, the story becomes an "icon" for another story. Moreover, the meeting of the common themes of different stories reinforces the effect of the often repeated idea that love transgresses all boundaries and defies 
limitations. In this respect, the lesbian love of Ali and the married woman is another variation that plays on this idea, which recalls the stories of both Francesca da Rimini and Paolo and Lancelot and Guinevere. While the stories of different characters meet in the literary realm, similar experiences of ordinary people meet in cyberspace as well:

When I sit at my computer, I accept that the virtual worlds I find there parallel my own. I talk to people whose identity I cannot prove. I disappear into a web of coordinates that we say will change the world. (93-4)

In the last part of the novel, "Save", the narrator again considers the waters of the Thames as something solid: as she looks at the river she thinks that it contains centuries "pumped into it" (243). To catch time, to be part of it, she dips her hands in the water calling it "Liquid time" (243). She says that there is no "date line, no meridian, no gas-burnt stars, no transit of the planets, not the orbit of the earth nor the sun's galaxy" (243). There is nothing to tell her the time. In an overarching attitude, she states that "Love is keeper of the clocks" (244). Then, feeling no need for a timepiece that will tell her the time, she takes off her watch and drops it in the water, and says that "The lover's body is my Book of Hours, the true history of the world is the one told by these bodies" (244).

In sum, the story, which takes place in the virtual world where the borders of identities are blurred, goes beyond a specific time and a specific character. As she trawls her screen, Ali, the e-storyteller says she is "looking for you, looking for me, trying to see the disguise. I guess I've been looking for us both all my life" (64). It seems that she is trying to build an identity for herself which is free from disguise and the limitations of time and space. In the part called "Own Hero", Winterson makes Ali explicitly talk about the need to be independent of borders and limits; she implies that only by making oneself the hero of one's life can the gap between many different heroes and heroines belonging to different times be bridged: "In this life you have to be your own hero. By that I mean you have to win whatever it is that matters to you by your own strength and in your own way" (155).

As she describes in "Own Hero", Winterson creates a unique hero in her novel who challenges gender roles through Internet and storytelling. This hero escapes the body and its physical confines, which also brings about a freedom from the social confines as well. Therefore, the fantastic image of grafting can be understood as a manifestation of these liberating possibilities in the patriarchal order.

Winterson's use of the motif of metamorphosis also functions as a criticism of the patriarchal order. Together with an anti-marriage attitude and the portrayal of the conditional love of parents based on the gender of their children, the image of transformation becomes a tool for criticism of the gender roles assigned by the patriarchal culture. The plant grafted between the thighs of Ali starts to respond to sexual desire, and the arousal she feels with the erection of the plant is followed by an act of ejaculation. The replacement of a penis by a plant provides an image of metamorphosis. The title of the section "OPEN HARD DRIVE" obviously has symbolic 
meaning; the entire section is an account of the adventure of the tulip that ends its journey in the vagina of a young bride-to-be, who has had no previous sexual intercourse. In addition, the icon introducing the section title, a lock-shaped tulip, recalls the chastity belts that were mythically used to protect young ladies from vaginal intercourse. Thus, when the narrator starts the section by saying: "I want to start with a tulip. In the sixteenth century the first tulip was imported to Holland from Turkey. I know-I carried it myself" (9), the reader is given the sign of the story in which a tulip, growing into a phallus, functions as an opener of the "hard-drive" (7). Namely, Ali's "tulip" acts as a penis and enters the young lady's body through her hymen. Therefore, Ali calls this the tulip that will open the so-called lock and so comprise the "Key of Pleasure and Lover's Dream" (9). Winterson gives a detailed account of what this "centrepiece" is like, which adds to the realistic effect that the fantastic image creates (12):

About eight inches long, plump, with a nice weight to it. We secured it to my person and inspected the results. There are many legends of men being turned into beasts and women into trees, but none I think, till now, of a woman who becomes a man by means of a little horticultural grafting. (12)

Then a "strange" thing happens; as the Princess, under whose service Ali has to work as a young gentleman to teach the young lady the games of love, kisses and pets Ali's tulip, Ali's sensations grow (22). In Ali's words, her disguise comes to life, namely it begins to stand up as if it were a real erect penis. The tulip is even represented as ejaculating. In this way, the fantastic image of an embalmed tulip worn as a centrepiece starts to work as an image of transgression:

I looked down. There it was, making a bridge from my body to hers.... I kneeled down, the tulip was waving at me as it had done on the hillside that afternoon I cut it down. Very gently the Princess lowered herself across my knees and I felt the firm red head and pale shaft plant itself in her body. A delicate green-tinted sap dribbled down her brown thighs. All afternoon I fucked her. (22)

In a similar fashion as theorised by Todorov, who regards the supernatural as the symbol for "dreams of power", ${ }^{23}$ the use of the fantastic makes it possible for the narrator of the novel to gain access to power; the "dream of power" comes true by a simple fantastic image. Through this fantastic image Winterson suggests that what Freudian theory sees as women's deficiency, or as "penis envy", can be replaced by a simple grafting from nature. A tulip can do what a penis can. The metamorphosis of an embalmed tulip into a penis acts as the agent of the collapse of the limit between a horticultural object and a human one. The image of a tulip functioning as a penis can be read as a challenge to the central place given to men in patriarchal culture; it implies the possibility of a woman's having sexual pleasure without a penis. Interestingly, Winterson's use of the word "centrepiece" for penis gains an ironic

${ }^{23}$ Todorov, 109. 
dimension in the sense that it parodies the central role given to men in phallocentric male order, namely patriarchy. Ali as a girl stating, "This was my centrepiece" (12) and "Her fingers had reached the centre" (22) shows how easily the seemingly sharp boundaries between the male and female sex organs are transgressed, thus how meaningless it is to cling to these boundaries. For Winterson, who sees lesbianism as the only way for real emancipation from patriarchal norms, the tulip as a supernatural element causes the limit to "cease to be impervious". ${ }^{24}$ Thus, the book itself becomes, as its title claims, "The PowerBook" that guides the reader into a world where dreams of power come true by making the females powerful enough to lead a life of their own.

The passages in the novel that relate the nature of the metamorphosis demonstrate that Winterson's use of the image of metamorphosis has a critical function. In fact, when Ali poses the question "What's so special about a tulip? Put it this way.... When is a tulip not a tulip?" she is the mouthpiece for Winterson's problematising of the established gender and sex roles in the patriarchal order (9). As is clear from the section under consideration, the penis is not the only means of giving satisfaction, and in this way, Winterson recalls the points raised by lesbian feminists. Among them, there is the discussion of phallocentrism, that is, of the dominant role ascribed to the penis in heterosexual relations in discouraging women from realising their sexual desire; and there is also the point that lesbianism is not only a sexual but a political choice. Lesbian feminists contend that just like gender, sex is a construction, therefore is subject to change. A seminal text by the early lesbian activists who call themselves "Radicalesbians", "The Woman Identified Woman" raised this issue in the early 1970s:

For a lesbian is not considered a "real woman". And yet in popular thinking, there is really only one essential difference between a lesbian and other women: that of sexual orientation-which is to say, when you strip off all the packaging, you must finally realise that the essence of being a "woman" is to get fucked by men. ${ }^{25}$

Charlotte Bunch in her 1972 article, "Lesbians in Revolt" (another historically important text of lesbianism), like the Radicalesbians, states that "Male society defines Lesbianism as a sexual act, which reflects men's limited view of women: they think of us only in terms of sex. They also say that lesbians are not real women." ${ }^{26}$ In an attempt to clarify the point, she says that the lesbian, "woman-identified-woman", centres her energies around women "not only as an alternative to oppressive male/ female relationships but primarily because she loves women". ${ }^{27}$ She sees the sexism which divides women into two separate groups as "the root of all oppression" and believes that "Lesbians must become feminists and fight against woman's oppression,

\footnotetext{
${ }^{24}$ Ibid., 113.

${ }^{25}$ Radicalesbians, 2.

${ }^{26}$ Bunch, 2.

${ }^{27}$ Ibid.
} 
just as feminists must become Lesbians if they hope to end male supremacy." 28 Lesbians, thus, attempt to struggle against the reductionist view of the public which sees lesbians as females whose main concern is the biological sex identity of their partners.

Like feminism, lesbian criticism questions and tries to challenge the privilege given to heterosexist and homophobic discourse which conditions people to think that gays and lesbians are perverse in nature. ${ }^{29}$ To refute male-centred arguments, lesbians discuss how women engage themselves in heterosexist relations. In the introduction to Contemporary Lesbian Writing: Dreams, Desire, Difference, Paulina Palmer recalls the question raised in the 1970s as to how most women submit themselves to heterosexual orientation, and quotes one woman telling her about their discussions on the origin of their sexual orientation:

We talked for hours about sex, problems with men, how we resented sex-roles ... all those kind of things. But we never wondered how we got to be heterosexual. The question just didn't arise. I suppose, like the rest of the world, we assumed that was the norm. So all our questioning about why a woman's role within heterosexuality is constructed in such and such a way, never once extended to questioning heterosexuality itself. ${ }^{30}$

In a critical approach to compulsory heterosexuality, Winterson presents the notion of a lesbian utopia where all the hierarchical relationships between men and women are destroyed. With her tulip which she can use as a penis, Ali becomes an agent defeating the superiority of the phallus in the patriarchal order. This image of grafting is also a form of articulation of Ali's rage against degradation as a female in the male order. The origins of the problem about gender and sex roles date back to her childhood:

When I was born, my mother dressed me as a boy because she could not afford to feed any more daughters. By the mystic laws of gender and economics, it ruins a peasant to place half a bowl of figs in front of his daughter, while his son may gorge on the whole tree, burn it for firewood and piss on the stump, and still be reckoned a blessing to his father. (10)

Gender roles are so discriminating and patriarchy's degradation of women is so deep, that, when Ali is born, her father even wants to drown her. Fortunately, her mother persuades her father to let her "live in disguise, to see if I could bring any wealth to the household" (11).

Winterson presents another story which is similar to Ali's in the sense that there is the same hostility towards female children. The narrator of this story, Alix, is represented as an orphan who is adopted by "superstitious people. The kind of

\footnotetext{
${ }^{28} \mathrm{Ibid}$.

${ }^{29}$ Zimmerman, 7-8.

${ }^{30}$ Palmer, 10 .
} 
people who kept a rabbit's paw in each pocket and a crucifix round the neck just in case" (137). When they are asked whether they want a girl or boy, they hastily turn to each other in panic as they have not thought of it before. And as the warden taps her foot impatient to get an answer, they immediately utter "Pink, please" (138). They think that "Girls are cheaper, easier and cleaner" (138). This negative attitude towards the female sex is made less central by the double use of the gender pronouns "his" and "her" for Alix. In other words, the use of both pronouns for the cross-dressed female characters in the novel helps Winterson to blur the dichotomy between the male and female sexes and gender roles. For instance, just as Ali is describing how she is dressed as a boy since her mother cannot afford to feed any more daughters, the narrator interferes and asks, "How could Ali barter philosophies when his bulbs were itching?" (18, my emphasis). Then, the narrator uses both his and her for Ali in the same paragraph. After asking "What happened to him?", the narrator starts talking about "her" and says, "When Ali unstrapped her bulbs and planted them in the good earth, she was obeying the command of the scriptures to go forth and multiply. Multiply she did" (213). Meanwhile, by referring to the power stories from the Bible, it seems that Winterson is adding one more story that shows the female sex as the potentially powerful sex, just like the male one in the patriarchal order. In that sense, once again the title of the novel makes the reader think that what they hold in their hands is a book that tells about and consists of alternative ways of existence for women in the patriarchal order.

Alix's parents' relationship to her also reveals this patriarchal hierarchy, and serves as a critique of the patriarchal family structure. In Muck House, where Alix lives with her family, reading and writing are forbidden, but as Alix says: "My mother could do both, my father could do neither, therefore they had no value" (140). The unequal power relationship dominates the house where there is no love. Love is fantastically put into a jar and treated as one of the chemicals on the father's shelf. This image functions as a critique of the male power in patriarchy. At the end of a row of jars, Alix finds an opaque one "with a heart drawn on it and a dagger through the heart" (142). This image on the jar, which is a mere cliché mostly used by teenagers, once again helps Winterson dramatise the father as a negative figure. As he sees Alix noticing the jar, he cries: "Never touch that jar. Never. If that ever gets loose we're finished" (142). Alix innocently asks why and the father's reply is symbolic of the family as a sterile institution of compulsory heterosexism: "Love. There's love in that jar" (142). Thus, Alix learns that love is a "hazardous liquid" and wants to leave for another world beyond "the Muck House" (142).

Alix's mother is represented as a pleasant person whose potential has been wasted in marriage and patriarchal gender roles. Unlike the father who never exchanges a word in conversation, she tells stories from her youth. As Alix listens to her stories, she infers that her mother's youth was like a "far-off city where she had lived for a time and been happy" (143). She is in "exile" from her past to which she can never 
return. Her tragic life makes Alix think that her past "is the only kingdom she could control" (143). As she rhetorically asks whether she will be young again, the father sarcastically replies, "You won't get any younger even if you clean your teeth twice a day" (144). So, when the fantastic image of grafting is read against this patriarchal concept of the family, it is apparent that the tulip has a critical function.

Ali underlines the significance of this image of metamorphosis herself and says: "There are many legends of men being turned into beasts and women into trees, but none I think, till now, of a woman who becomes a man by means of a little horticultural grafting" (12). Ali dresses as the opposite sex and changes her sex role. She carries a tulip and a pair of bulbs "sewed on to a narrow leather strap and fastened round the hips" that recalls some artificial phallus designed for increasing sexual pleasure (11). Ali is like the girls in the The Arabian Nights who try to preserve their virginity in the course of the ordeal they are forced into by patriarchal power relations. She is on a journey to take the tulip from the Ottoman Empire to Holland in the sixteenth century, the Tulip Era. The theme of the journey and the theme of cross-dressing evoke The Arabian Nights as does the historical and the geographical base to Ali's story. Later in the novel, Winterson herself seems to draw an analogy between the tale of Ali and the tales in The Arabian Nights collection:

It has not been proved, but it might be so, that Ali is not telling stories, but that the stories are telling him. As he knots himself into a history that never happened and a future that he cannot have, he is like a cross-legged Turk who knots a fine carpet and finds himself in the pattern.... Ali tells stories. He puts himself in the stories.... What he is, what he invents, becomes part of the same story, one continuous story, where even birth and death are only markers, pauses, changes of tempo. (214-15)

Ali telling stories is presented as an endless story which will probably "shift to other mouths and other tales, while Ali, with his tale in his mouth, rolls on" (214-15). The girls in disguise in the traditional tales finally reveal their identity and submit themselves to the traditional plan made for them by the patriarchal ordereither marriage or a return to the family. However, Ali of The PowerBook is on the run. The often-repeated line, which is the opening sentence of the novel, "To avoid discovery I stay on the run. To discover things for myself, I stay on the run", implies that Ali avoids the act of discovery which would offer her a typical life in the male order (3). As she feels that the act of uncovering her identity would mean a total surrender to patriarchy, Ali stays on the run. She describes the nature of her disguise by referring to the basic needs of animals; thus she justifies the act of disguise in the male order:

An animal hides to save itself.... I know about disguise. I disguise myself from predators. I disguise myself from circumstance. The camouflages I use are elaborate, but I know what they are. Even my body is in disguise today. But what if my body is the disguise? What if skin, bone, liver, veins, are the things I use to hide myself? I have put them on and I can't take them off. (15) 
She feels that her life is "steel-hitched at one end into [her] mother's belly, then thrown out across nothing, like an Indian rope trick" (210). The following comment she makes upon her life is like a manifesto which articulates the transgression of the boundaries and reconstruction of identity in the male order:

Continually I cut and retie the rope. I haul myself up, slither down. What keeps the tension is the tension itself-the pull between what I am and what I can become. The tug of war between the world I inherit and the world I invent. I keep pulling at the rope, I keep pulling at life as hard as I can. (210)

In conclusion, Winterson elaborates on the pull between what one is and what one becomes. She does this by employing the fantastic image of grafting. In this way, the fantastic becomes a critical tool for making the reader aware of the confines of gender roles and identity in the patriarchal order. Throughout the novel, Ali provides the reader with an alternative female role model-one who travels long distances in the sixteenth century and implies that, one does not have to be a man to be in love with a woman. In this way, Winterson suggests a transgression not only of the gender roles but also of the sex roles accepted in the patriarchal order.

\section{References}

Bersani, Leo. A Future for Astyanax: Character and Desire in Literature. Toronto: University of Toronto Press, 1976.

Bunch, Charlotte. "Lesbians in Revolt." The Furies: Lesbian/Feminist Monthly 1 (1972): 8-9. Documents from the Women's Liberation Movement: An On-line Archival Collection, Special Collections Library, Duke University. [cited 15 February 2005]. Available from http:// scriptorium.lib.duke.edu/wlm/furies/.

DeLombard, Jeannine. Review of The PowerBook, by Jeanette Winterson. Lambda Book Report 9, no. 5 (2000): 17.

Gautier, Theophile. “The Beautiful Vampire.” In Fantastic Tales: Visionary and Everyday, edited by Italo Calvino. New York: Pantheon Books, 1997.

Hoffmann, E. T. A. “The Sandman.” In Tales, edited by Victor Lange. New York: Continuum, 1982.

Irigaray, Luce. "Women on the Market." In This Sex Which is not One. Translated by Catherine Porter with Carolyne Burke. New York: Cornell UP, 1985.

Jackson, Rosemary. Fantasy: The Literature of Subversion. London and New York: Routledge, 1981.

Lacan, Jacques. Ėcrits: A Selection. Translated by Alan Sheridan. New York: W. W. Norton and Company, 1977.

Palmer, Paulina. Contemporary Lesbian Writing: Dreams, Desire, Difference. Buckingham: Open University Press, 1993.

Radicalesbians. "The Woman Identified Woman." Pittsburgh, Penn.: Know, Inc., c. 1970. Documents from the Women's Liberation Movement: An On-line Archival Collection, Special Collections Library, Duke University. [cited 15 February 2005]. Available from http:// scriptorium.lib.duke.edu/wlm/womid/.

Reynolds, Margaret, and Jonathan Noakes. "Interview with Jeanette Winterson by Margaret Reynolds." In Jeanette Winterson: The Essential Guide. London: Vintage, 2003.

Stevenson, Robert Louis. The Strange Case of Dr. Jekyll and Mr. Hyde. New York: Dover Publications, Inc., 1991. 
304 M. Özyurt Kılıç

Suler, John. Psychology of Cyberspace. January, 1996. [cited 20 February 2004]. Available from http://www.rider.edu/ suler/psycyber/.

Todorov, Tzvetan. The Fantastic: A Structural Approach to a Literary Genre. Translated by Richard Howard. Ithaca, N.Y.: Cornell University Press, 1975.

Winterson, Jeanette. The PowerBook. London: Jonathan Cape, 2000.

Zimmerman, Bonnie. "Lesbians Like This and That: Some Notes on Lesbian Criticism for the Nineties." In New Lesbian Criticism: Literary and Cultural Readings, edited by Sally Munt. Exeter: Harvester and Wheatsheaf, 1992. 